\title{
APPLICATION OF GREEN TECHNOLOGIES IN IRRIGATION
}

\author{
Lyudmila Nikolaevna Medvedeva ${ }^{1,2,}$, and Artem Vladimirovich Medvedev ${ }^{1}$ \\ ${ }^{1}$ Federal State Budget Scientific Institution «The All-Russian research institute of irrigated agriculture», Volgograd, Russia \\ ${ }^{2}$ Volzhsky Polytechnic Institute (branch) of Federal State Budget Educational Institution of Higher Education Volgograd State Technical \\ University, Volgograd, Russia
}

\begin{abstract}
The article presents materials which reveal the using of green technologies (renewable energy sources) at the site of the irrigation complex of agriculture. In the article an option for placing solar panels on the Prigorodny irrigation system of the Krasnodar Territory of the Russian Federation is proposed to cover the power consumption of the units of the head pumping station PS 123 . Engineering, technical and economic calculations of design, installation, and placement of solar panels of two types with a capacity of 200 watt were carried out. According to the application of Russian solar panels, the investment requirement is 1,845 billion rubles, with a payback period of 10, 2 years. Organizational and legal tools for attracting investments in the land reclamation complex of the country's agriculture using the mechanism of publicprivate partnership and the infrastructure of land reclamation parks is justified.
\end{abstract}

\section{Introduction}

The development of the world food market is proceeding in rather difficult conditions, in the midst of contradictions between the main actors in this process the leading countries of agricultural production [1,2]. The government of the Russian Federation has adopted the export strategy, according to which the country should strengthen its presence in the world food markets by 2050 "conquer" a segment of $15 \%$. The solution of this problem lies in the development of water and land resources through the using of innovative agricultural technologies. One of the institutional and infrastructural objects which can speed up the process of agricultural production is the Land improvement Parks (hereinafter L.I.P.), a model of which was developed by Russian scientists. [3,4]. A L.I.P is a territorial, technological, technical, scientific base, provided with the necessary administrative and legal conditions for the development of land reclamation and the production of agricultural products. The main investor of the L.I.P is the state, which invests funds from the federal and regional budgets in the construction, reconstruction, technical reequipment of reclamation systems. Residents of the L.I.P. are agricultural producers after the commissioning of reclaimed land, reimburse the state $30 \%$ of the invested funds within 7 years [4].

One of the important aspects of agricultural production at the site of the L.I.P. is using of green technologies and improving energy efficiency. Renewable or "green energy" is energy that is obtained through processes occurring in the environment. In 2019, $28 \%$ of global energy consumption came from renewable energy sources (hereinafter referred to as renewable energy) [5].One of the components of RES is solar generation, based on the conversion of electromagnetic solar radiation into electrical or thermal energy. European Electricity Association «Eurelectric» has published in «Power Barometer» key indicators that reflected the development of the energy sector and identify the risks posed to building a climate-neutral European economy by 2050. «Barometer» shows that by 2030, the number of EU countries that will not have coal-fired generation will reach 21 [5]. According to Bloomberg NEF experts, the gap between solar and wind energy will grow. According to their forecasts, from 130 to $170 \mathrm{GW}$ of solar capacities will be built annually against 50-60 GW of wind power. In total, the installed capacity of green energy (including hydropower) at the end of 2019 amounted to about 2, 5 TW [6]. The main RES producers are China, Great Britain, the USA and Germany (20 GW) [6]. To promote renewable energy sources, the government of the Russian Federation has developed an Action Plan to stimulate the development of generating facilities based on renewable energy sources with an installed capacity of up to $15 \mathrm{~kW}$. The positive aspects of using RES include: inexhaustibility, environmental friendliness, speed of construction, low cost of energy received during operation. Negative aspects are: dependence on weather conditions and geographic location, low efficiency. At the same time, in 2020, a consortium of German scientists announced the development of solar panels based on perovskite and silicon with an efficiency of $33 \%$, which is $50 \%$ better than the current record for solar panels of $22,3 \%$ [6]. The efficiency and feasibility of converting solar energy into electricity and heat largely depends on the potential of the territories. For example, in regions with a high potential for solar radiation, the creation of tower and modular power plants and solar power plants using solar

\footnotetext{
* Corresponding author: milena.medvedeva2012@yandex.ru
} 
Table 1. Duration of sunshine in the Krasnodar Territory of the Russian Federation, hours.

\begin{tabular}{|l|l|l|l|l|l|l|l|l|l|l|l|l|}
\hline Size & I & $\Pi$ & III & IV & V & VI & VII & VIII & IX & X & XI & XII \\
\hline Average & 71 & 83 & 130 & 181 & 242 & 289 & 323 & 291 & 239 & 173 & 95 & 57 \\
\hline Maximal & 166 & 131 & 187 & 255 & 337 & 362 & 393 & 363 & 317 & 253 & 167 & 131 \\
\hline Minimal & 27 & 37 & 79 & 100 & 159 & 200 & 252 & 214 & 161 & 108 & 43 & 18 \\
\hline Year & 1967 & 1924 & 1924 & 1955 & 1915 & 1917 & 1925 & 1976 & 1929 & 1914 & 1955 & 1927 \\
\hline
\end{tabular}

ponds in conjunction with wind power plants (WPP) allows these regions to be provided with electric energy by $95 \%$. In the South of Russia and the southern part of Siberia, the annual number of sunshine hours makes it possible to use solar generation quite effectively. In these regions, due to high solar radiation and a large number of hours with sunshine, the using of solar power can be significantly cheaper than the cost of $1 \mathrm{kWh}$ of thermal energy used from a thermal power plant (hereinafter referred to as TPP). In the global economy, there are examples of using of solar energy in irrigation facilities. For example, in the state of Gujarat, India, the state-owned generating company «Mahagenco» has placed solar panels above irrigation canals and uses the resulting energy to supply water to farmers [7].

The placing solar panels over irrigation canals ensure the implementation of several goals: reducing capital costs by placing solar panels above irrigation canals (saving on the allocation of land for development); reduction of water loss from water bodies by reducing evaporation; cooling of panels due to the water surface; obtaining clean energy; creation of new jobs. The purpose of the study is to consider the possibility of using green technologies at irrigation facilities based on the economical mechanism of public-private partnership.

\section{Materials and methods}

The article presents engineering and technical, economical and mathematical calculations to justify the placement of solar panels over irrigation canals in the South of Russia. A Prigorodny irrigation canal (PIC), which is part of the Kuban melioration system, was chosen as the object. The using of monitoring methods, comparative analysis, regulatory, computational and constructive modeling made it possible to justify the implementation of a project to create a solar generation complex over an irrigation facility using the mechanism of public-private partnership.

\section{Results and reasoning}

The Krasnodar region of the Russian Federation, due to its physical and geographical position (coordinates: $43^{\circ}$ $30^{\prime}-46^{\circ} 30^{\prime} \mathrm{N}$, determines the height of the sun above the horizon, the angle of inclination of the sun's rays from $68^{\circ} 33$ 'at noon on June 22 to $21^{\circ} 30^{\circ}-22$ December), has a lot of sunshine. Annual amount of heat in the north of the region is 115 , and in the south -120 $\mathrm{kcal} / \mathrm{cm}^{2}$. In summer, the total radiation is 48 and in winter - up to $12 \mathrm{kcal} / \mathrm{cm}^{2}$, except for the winter period, in all other periods of the year there is a positive heat balance, more than $45 \mathrm{kcal} / \mathrm{cm}^{2}$. The height of the sun in winter is less than $30^{\circ}$, from March to September - more than $45^{\circ}$. The duration of the sunshine is 2200-2400 hours per year; the average duration of sunshine per year is 2174 hours, while the annual maximum is observed in July (323 hours), and the minimum - 57 hours in December, which indicates the economic feasibility of using green technologies - RES (table 1) [8,9].

There are 16 irrigation systems in the Krasnodar Territory, including: Fedorovskaya, Temryukskaya, Kryukovskaya, Prigorodny. The functioning of the irrigation system is ensured by the State Institution "Management of Land Reclamation and Water Management of the Krasnodar Territory" (hereinafter the Kubanmeliovodkhoz Institution), which is under the jurisdiction of the Ministry of Agriculture of the Russian Federation [8]. The main activity of the Kubanmeliovodkhoz Institution is to create the necessary conditions for increasing the production of high-quality agricultural products based on the restoration and increase of soil fertility of agricultural lands while performing a complex of irrigation, drainage, cultural, water management, and organizational measures during the operation of irrigation systems [9].

The economic activity of the organization consists of funds allocated from the federal center and payments for services provided, the main of which is the supply of water by agricultural producers. The Kubanmeliovodkhoz Administration spends up to $78 \%$ of the allocated federal money to pay for electricity for the operation of pumping stations. One of the possible options for reducing the costs of the organization is to obtain energy from solar energy panels (placing solar panels on one of the main canals). The aim of the research was to determine the section of the main irrigation canal for the placement of solar panels. The most preferred place was the Prigorodny irrigation system, built in 1985, located in the northeastern Prigorodny part of the city of Krasnodar. The irrigation system serves 18 large water users of various organizational and legal forms of ownership (CJSC, LLC, SEC), as well as owners of personal subsidiary farms. The irrigation zone of the Prigorodny irrigation system includes agricultural fields of SEC «Krasnodarskiy», agricultural firms of «Solnechnaya». The main water intake for the system is carried out from the headwaters of the Krasnodar reservoir by pumping station № 1, and water is discharged through the Azov rivers Kochety and Ponura. The total irrigated area in the main canal zone is 23, 3 thousand hectares. Placing solar panels above the irrigation canal, it was necessary to solve a number of organizational problems: to identify the prospective customers, investors, contractors and 
Table 2. Hydraulic elements in the ponds of the area under consideration of MC.

\begin{tabular}{|c|c|c|c|c|c|c|c|}
\hline $\begin{array}{c}\text { The } \\
\text { number of } \\
\text { pool }\end{array}$ & Roughness & Slope & $\begin{array}{c}\text { Pool length, } \\
\mathrm{m}\end{array}$ & $\begin{array}{c}\text { Creation of a } \\
\text { slope }\end{array}$ & $\begin{array}{c}\text { Bottom } \\
\text { width, } \mathrm{m}\end{array}$ & $\begin{array}{c}\text { Water } \\
\text { withdrawal } \\
\mathrm{m} / \mathrm{s}, 95 \%\end{array}$ & Normal depth, $\mathrm{m}$ \\
\hline 3 & 0.017 & 0.0003 & 4500 & 2 & 2 & 1.2 & 2.041 \\
\hline 4 & 0.017 & 0.0004 & 3500 & 2 & 1 & 1.2 & 2.041 \\
\hline 5 & 0.017 & 0.0004 & 2250 & 2 & 1 & 1.2 & 1.953 \\
\hline 6 & 0.02 & 0.00045 & 3500 & 2 & 1.5 & 1.2 & 1.836 \\
\hline 7 & 0.02 & 0.0006 & 4000 & 2 & 1.5 & 1.2 & 1.641 \\
\hline 8 & 0.025 & 0.0004 & 5000 & 2 & 1.5 & 0.9 & 1.855 \\
\hline
\end{tabular}

consumers. The research shows that the Project can be implemented on the basis of a public-private partnership mechanism and the infrastructure of a L.I.P $[10,11]$. The organizational and legal form of the Project implementation can be a L.I.P. created on the basis of voluntary participation of partners, whose members can become 23 water users (18 large farms, owners of personal subsidiary farms). The benefit is that the energy received from the solar panels will remain the property of the residents of the L.I.P., which will reduce the level of payment of water supply to the fields. As a result of the implementation of the Project, the Kubanmeliovodkhoz Administration will be able to reduce its costs of purchasing energy from generating companies, and to form an optimal price for water supply, taking into account the interests of the L.I.P. residents. According to the Project, during the growing season (180 days), $90 \%$ of the generated electricity will be used to ensure the operation of the pumping station, the remaining period (185 days); the energy comes from solar generation, can be used by the members of the cooperative for their own needs or sold outside [12].

\section{Project implementation}

The main canal of the Prigorodny irrigation system has the following characteristics: safety level is satisfactory, the state of the channel - concrete and earthen; the technical assessment of the channel is satisfactory. The total capacity of the head pumping station (hereinafter MPS) $\mathrm{HC}-123.4 \mathrm{~m}^{3} / \mathrm{s}$, the power consumption of all units is $4535 \mathrm{kWh}$. The pumping station is equipped with 7 pumping units with efficiency $3.2 \mathrm{~m}^{3} / \mathrm{s}$, with capacity of electric motor $630 \mathrm{kWh}$. There is also a standby unit of the brand OB6-55 with efficiency $1 \mathrm{~m}^{3} / \mathrm{s}$, with capacity of electric motor $125 \mathrm{kWh}$. Pumping station HC-1 has been in operation since 1978 without replacement of equipment, as a result, the real energy consumption exceeds the design. The total irrigation area of the irrigation system according to the design data is 23 940 hectares, and irrigation in 2020. was produced only on an area of 5.888 hectares $[11,12]$. The considered section of the main canal originates between the «Znamensky» dacha partnership and the Prigorodny settlement and ends in the area of the Lazurny settlement (from the third head of the canal to the eighth the project section is $22,75 \mathrm{~km}$ long. The channel width at the top is $12 \mathrm{~m}$, which can be taken as the width of the placement of solar panels. The total area of the panels placement is $273000 \mathrm{~m}^{2}$ (table 2).

The layout of solar panels for the project under consideration is shown on the Fig. 1.

The calculation of the efficiency of the Project was based on the calculation of the power consumption of the head pumping station for the growing season (operating time of the canal) and the cost of electricity consumed by it (the calculation of the cost of electricity required for the MPS was carried out at the tariff of the second half of 2019, 5.59 rubles per $\mathrm{kWh}$ ); the number of solar
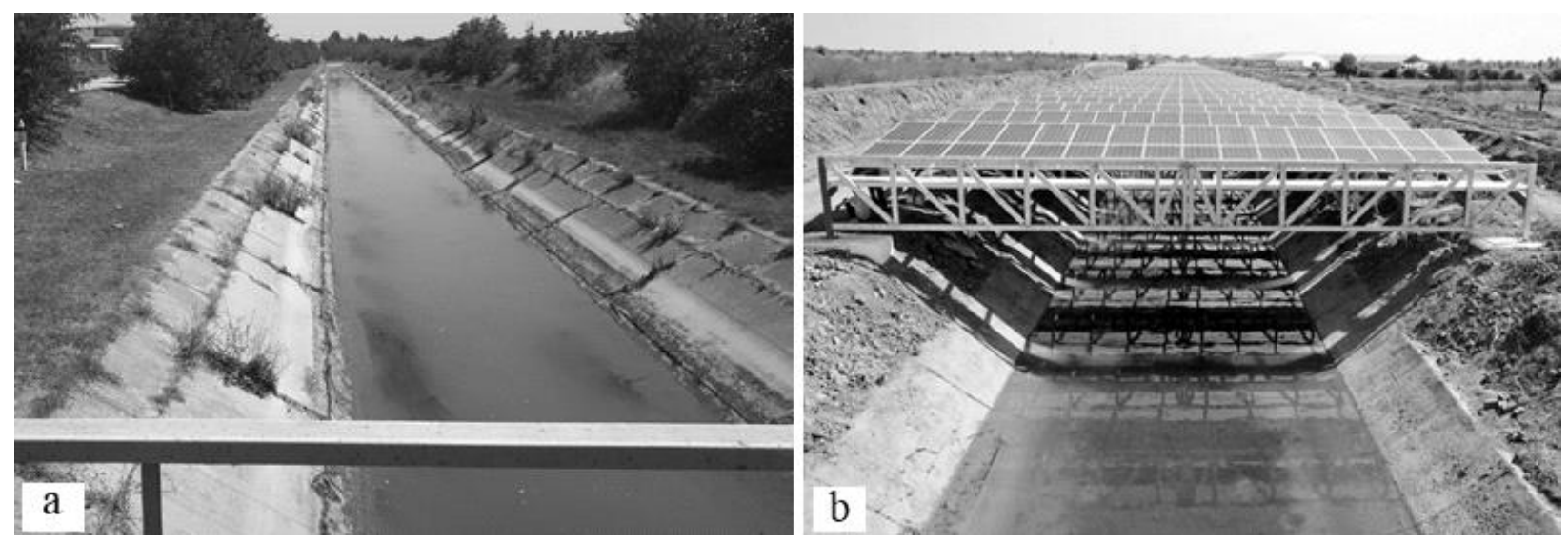

Fig. 1. a-view of the canal at the beginning of the sixth pool of the Prigorodny irrigation system for placing solar panels according to the project; b-layout of solar panels on the main canal « PIC » (the project of placing solar panels over a canal in Gujarat, India). 
Table 3. Calculation of indicators of MPS.

\begin{tabular}{|c|c|c|}
\hline Indicator & Unit & Size \\
\hline Power of MPS units (HC-1 23) & $\mathrm{kWh}$ & 4535 \\
\hline $\begin{array}{l}\text { Power consumption of MPS during the channel operation } \\
(\approx 180 \text { days })\end{array}$ & $\mathrm{mWh}$ & 19591.1 \\
\hline Electricity costs for MPS (5.59 rubles per kW·hour) & million rubles & 109.51 \\
\hline
\end{tabular}

Table 4. Calculation of costs for the purchase and installation of solar panels for the Project.

\begin{tabular}{|c|c|c|c|}
\hline Indicator & Unit & KCM-200 & CHN 200W-72M \\
\hline Capacity & $\mathrm{kWh}$ & 200 & 200 \\
\hline Overall dimensions & $\mathrm{mm}$ & $1586 \times 806 \times 35$ & $1580 \times 808 \times 35$ \\
\hline The service life & years & 25 & 25 \\
\hline Panel area & $\mathrm{m}^{2}$ & 1.278 & 1.276 \\
\hline Power from $1 \mathrm{~m}^{2}$ & Wh & 156.46 & 156.66 \\
\hline Power from $1 \mathrm{M}^{2}$ for the growing season ( 1557 hours) & $\mathrm{kWh}$ & 243.6 & 243.92 \\
\hline $\begin{array}{l}\text { Panel area required to meet the energy consumption of the } \\
\text { MPS }\end{array}$ & $\mathrm{m}^{2}$ & 80423 & 80318 \\
\hline Length of MC section for panels placement & $\mathrm{m}$ & 6702 & 6693 \\
\hline Required number of panels & psc & 62914 & 62913 \\
\hline Cost of one panel & rubles & 19500 & 9090 \\
\hline The sum of all panels in the calculated area & thousand rubles & 1226.8 & 571.9 \\
\hline $\begin{array}{l}\text { The cost of installing panels on a site (assuming that the } \\
\text { installation of } 1 \text { panel is } \approx 3,000 \text { rubles) }\end{array}$ & thousand rubles & 188.7 & 188.7 \\
\hline Total & thousand rubles & 1415.5 & 760.6 \\
\hline
\end{tabular}

panels required to cover these electricity costs was calculated, their cost and installation costs were determined. The payback period of the Project was calculated as the ratio of the total costs of solar panels to the amount of the estimated income from the sale of electricity to the population and the funds saved in connection with its own generation of electricity for the MPS during the year. The calculation was carried out for both domestic and Chinese solar panels, because they are the best-selling solar panels on the world market [12, 13]. From the range of panels considered, two models were selected: KCM-200 (200 W) from GmbH Kvant (Moscow) and CHN 200W-72M (200 W) from Chinaland Solar Energy Co., Ltd. (China), supplier LLC «Clean Energy» [14, 15, 16]. The calculations are summarized in tables 3,4 .

As a result of a preliminary calculation, it was established that the cost of electricity for the MPS during the operation of the channel, and therefore the amount of savings in the case of using solar panels, will amount to 109 , 51 million rubles during the year. The cost of electricity generated in the winter (for 617 hours) for the needs of the population will be 35,79 million rubles. Consecuently, with the total cost of installing the KCM200 panels $(1415,5$ thousand rubles) and CHN 200W$72 \mathrm{M}$ panels (760, 6 thousand rubles), the payback period will be 10, 2 years and 6,6 years, respectively.

\section{Findings}

The use of renewable energy sources is one of the promising areas in the world economy, which allows to reduce the cost of production in agriculture. To promote renewable energy sources into the national economy, the Government of the Russian Federation has developed an
Action Plan to stimulate the development of generating facilities based on renewable energy sources with an installed capacity of up to $15 \mathrm{~kW}$ [6]. The implementation of this plan will make it possible to simplify the process of placing solar generation facilities, will provide their owners with the opportunity to sell surplus generated electricity to the general grid. The calculation results of the Project shows that solar panels placed above the main canals can be quite effective. The use of the mechanism of public-private partnership at the site of the L.I.P. allows accumulating funds of investors to provide water users with cheaper energy, which makes it possible to form a lower price for payment of water supply services.

\section{References}

1 V. Melikhov, L. Medvedeva, A. Novikov, O. Komarova, Green Technologies: the Basis for Integration and Clustering of Subjects at the Regional Level of Economy, Integration and Clustering for Sustainable Economic Growth, 365 (2017)

2. S. Solomon, Climate Change 2007 The Physical Science Basis (Cambridge, United Kingdom and New York NY Cambridge University Press, 2007, 996)

3. L. Medvedeva, D. Belykh, A. Vagner, A. Medvedev, P. Vaneeva, I. Bondarik, Foresights technologies in the development of land Improvement parks in the countries - participants of Eurasec, World Irrigation Forum (WIF3) Bali Indonesia, 173 (2019) 
4. G. Balakay, Melioration park - infrastructure for agricultural development at the regional level, Melioration and water management, 6, 8 (2018)

5. Share of RES in electricity generation in the EU [Electronic resource] Available at: https://renen.ru/dolya-vie-v-vyrabotkeelektroenergii-v-es-dostignet-60-k-2030-godu

6. The sun overtakes the wind in energy [Electronic resource] Available at: https://eenergy.media/2020/09/10/solntseobgonyaet-veter-v-energetike/

7. Alternative energy: India [Electronic resource] Available at: http://energyland.info/news-showmir-alternate-146068.html

8. V. Shchedrin, S. Vasilyev, A. Kolganov, L. Medvedev, A. Kupriyanov, Meliorative institutional environment: the area of state interests, Espacios, 39, 28 (2018)

9. Federal State Budgetary organization «Kubanmeliovodkhoz» Suburban irrigation system [Electronic resource] Available at: http://www.kmvh.ru/mhm3.html

10. S. Manzhina, Modern approaches to determining the economically justified cost of water supply for irrigation, Scientific journal of the Russian research, Institute of reclamation problems, 3 (31), 148 (2018)

11. A. Kvitko, A. Khickova, Wind characteristics, features of calculating the resource and economic efficiency of wind energy, 97 (03), 1 (2014)

12. V. Shchedrin, Externalities of the improvement park in the field of the use of renewable energy sources, Drucker's bulletin, 4 (24), 106 (2018)

13. C. Burt, S. Styles, Journal of Irrigation and Drainage Engineering, 126 (5) (2000)

14. LLC «Clean Energy»: Solar battery CHN 200W72M (200 Bt) Chinaland Solar Energy Co., Ltd. [Electronic resource] Available at: https://alenergy.ru/magazin/product/solnechnaya-batareyachn-200w-72m

15. V. Korzhov, O. Sorokina, T. Korzhova, G. Matvienko, Analysis of the influence of new means and methods of irrigation on water distribution management processes, Scientific journal of the Russian research, Institute of reclamation problems, 4 (32), 105 (2018)

16. S. Vasiliev, V. Bondarenko, G. Senchukov, V. Gostischev, Conceptual basis of methodology of improving the technology of water use for irrigation and watering systems, Earth and Environmental Science, 1, 341 (2019). 